\title{
The Concept of Sustainability among Elementary Students in Brazil
}

\author{
Edson Grandisoli \\ Consultant on \\ Education for \\ Sustainability
}

\author{
Rosiani Telles \\ Colégio \\ Bandeirantes
}

\author{
Cristiana M. Assumpção \\ Colégio \\ Bandeirantes
}

\author{
Denise Curi \\ Colégio \\ Bandeirantes
}

\begin{abstract}
Rarely is the systemic concept of sustainability properly understood by teachers and students. The aim of this study is to assess knowledge, attitudes and behaviours towards the concept of sustainability among elementary students from $6^{\text {th }}$ to $9^{\text {th }}$ grades (ages ranging from 10 to 14 years old) at a private school in São Paulo, Brazil. Distributed in five sessions, a-40 structured questionnaire was designed to obtain that information. The results indicated that students from different grades present a similar level of knowledge, attitudes and behaviours regarding sustainability. Results were compared using the Chi-square test of homogeneity ( $\alpha=5 \%$ ) and most of the answers ( 94\%) were not significantly different among the grades. The results will guide teachers of different disciplines on what and how to better introduce the theme in their curricula, gradually increasing the comprehension about the complexity of the concept along the grades, aiming at a more sustainable school and society.
\end{abstract}

\section{Introduction}

Several different definitions and interpretations have been attributed to the concept of sustainability (or sustainable development) that is related to its purpose and context [1].

The UN's International Environmental Forum identified no less than 1,000 distinct definitions for "sustainable development" [2], which derives into the recently concept of "sustainability".

Despite differences, a number of common principles are embedded in most definitions of sustainability, such as nature and natural resources conservation (ecology), social equality (equity) and integration of environmental and economic goals (economy). This triad was formerly known as the 3 E's.

In sum, in a sustainable world, environmental protection, social respect and economic viability should be linked in harmony [3].
"Education is an essential tool for achieving sustainability. People around the world recognize that current economic development trends are not sustainable and that public awareness, education, and training are the key to moving society toward sustainability [4]".

The United Nations Decade of Education for Sustainable Development (2005-2014), for which UNESCO is the lead agency, seeks to integrate the principles, values and practices of sustainable development into all aspects of education and learning, in order to address the social, economic, cultural and environmental problems we have been facing in the 21st century [5].

Considering this approach, the concept of sustainability must be tackled with vigour, understood and taught in schools in order to build a complex, systemic and integrated view of the nature-society relationships.

Several different countries in Europe, North America and Oceania are already taking part in the concept of Eco-Schools, an international program for environmental education and management, aiming at raising students' awareness of sustainable development issues through classroom study as well as school and community action [6].

That is not an easy task for government, teachers and young students to achieve in most of the South America countries, especially because these objectives are not yet explicitly contemplated in most of their basic education curricula.

Nevertheless, before introducing the theme "sustainability" in the curriculum and disciplines, it is crucial to investigate and understand what students think and understand about "sustainability", and how they believe that their daily actions are contributing or not - to the construction of a sustainable world. This information builds an essential foundation for a systematic planning, implementation, and long-term activities outcome evaluation [7], aiming at the construction of new values and behaviours, and a more sustainable school and society.

Thus, the objective of this study is to assess knowledge, attitudes and behaviours about the concept 
of "sustainability" among young elementary students from $6^{\text {th }}$ to $9^{\text {th }}$ grades (from 10 to 14 years old) in a private school in São Paulo, Brazil.

The results will guide teachers in different programs on how to better introduce the theme in their classes, and in the school curriculum as a whole.

\section{Methodology and analysis}

This research was carried out by the "Education for Sustainability Project”, an extracurricular activity launched in January, 2010 at Colégio Bandeirantes, São Paulo, Brazil. 29 high school students (from 14 to 16 years old) and a team of 6 teachers are currently involved with the project.

In order to assess knowledge, attitudes and behaviour towards sustainability, the group designed a 40-question structured non disguised questionnaire [8].

Most of the questions were designed based on information gathered by two previously conducted focal groups ( $\mathrm{n}=19$ students) and tested in a pilot ( $\mathrm{n}=45$ $6^{\text {th }}$ to $9^{\text {th }}$ grade students' randomly selected).

The questionnaire was divided in 5 sessions, each of them assessing different aspects of the concept of sustainability, as follows:

Session 1: "The Imaginary": closed questions were designed to assess the level of indifference or concern regarding sustainability (awareness);

Session 2: "The Concept of Sustainability": opened and closed questions were designed to assess knowledge regarding sustainability;

Session 3: "Attitudes": using an adapted five-level Likert scale [9], students were evaluated about the importance of some every day actions (from "not important" to "very important") to transform the world into a more sustainable place. For that, we crafted 15 different statements (including three reverse-coded sentences) that had direct relationship to the three typical constituents of the "sustainable development" and "sustainability" concept: ecology (environment), economy and equity.

Session 4: "Constraints and Behaviour": using an adapted five-level Likert scale, students evaluated how difficult it would be for them (from "very easy" to "very difficult") to perform the actions mentioned on session 3. In addition, through a closed question, they answered if they perform that action in their daily lives using "yes", "no" or "sometimes";

Session 5: "My School": closed and open questions were designed to assess how students were used to seeing their school regarding the concept of sustainability.

The answers from $6^{\text {th }}$ to $9^{\text {th }}$ grade students were compared using the chi-square test of homogeneity $(\alpha=5 \%)$, and for those found significantly different, the Wilcoxon non-parametric test $(\alpha=5 \%)$ was applied [10, 11].

\section{Highlights on results}

Since the questionnaire is composed by 40 opened and closed questions, it is not possible to discuss all outcomes. Thus, we will present some of the results we considered the most interesting and representative and that can bring up some new perspectives towards the concept of sustainability.

In total, 113 students from $6^{\text {th }}$ to $9^{\text {th }}$ grade attended to the survey (table 1).

Table 1. Absolute and relative number of students surveyed per grade

\begin{tabular}{|c|c|c|c|}
\hline Grade & $\begin{array}{c}\text { Random } \\
\text { sample }\end{array}$ & $\begin{array}{c}\text { Total of } \\
\text { students per } \\
\text { grade }\end{array}$ & Percentage \\
\hline $6^{\text {th }}$ & 29 & 191 & $15 \%$ \\
\hline $7^{\text {th }}$ & 29 & 205 & $14 \%$ \\
\hline $8^{\text {th }}$ & 28 & 242 & $12 \%$ \\
\hline $9^{\text {th }}$ & 27 & 303 & $9 \%$ \\
\hline Total & 113 & 941 & $12 \%$ \\
\hline
\end{tabular}

\subsection{Session 1}

In the first part of the questionnaire, the student's answers pointed out that most of them had already heard about "sustainability" (96\%) but they were not sure if they knew the updated meaning of the word once $65 \%$ answered "I guess so" to the question "Do you know what is the meaning of the word sustainability?”

In addition, 91\% thought that it was important for everybody to act in a sustainable way but they used to act like that only "Sometimes" (67\%).

Only $14 \%$ of the students surveyed actively look for information regarding the theme "sustainability", and when it happens, the internet, the television and the school are the most important information sources. All the three sources of information cited in the questionnaire were chosen by approximately $23 \%$ of the students.

Finally, about $40 \%$ were really interested in knowing more about sustainability while $60 \%$ showed some interest about that.

\subsection{Session 2}

It seems that there has been a consensus among students when they were questioned about the sustainability concept: $71 \%$ agreed that sustainability can be seen as the main reason to preserve natural resources and the environment, and only 9\% consider easy to make the world a sustainable place.

Those results match with the opened question: "What comes to your mind when you hear the word sustainability?" Following the same pattern, the most common answers were related to environment and preservation of natural resources, such as: saving energy, saving water, trees, environment, Global Warming etc. Only one $9^{\text {th }}$ grade student cited 
“consumerism” and two $8^{\text {th }}$ graders cited “education”, "respect” and "citizenship".

When asked about who could be responsible for the building of a more sustainable society, 25\% answered Educational Institutions, while $30 \%$ said the Government.

In addition, through an opened question, the students also had the opportunity to write who else would be responsible for the building of a more sustainable world. 29\% considered that "everybody" must be responsible, and only one student (0.9\%) answered that "himself (or herself)" is responsible for that.

Unfortunately it is not possible to evaluate if the $29 \%$ of the students that answered "everybody" consider themselves as part of the process. Nevertheless, that was an important result allowing us to go further in our investigation.

\subsection{Sessions 3 and 4}

Recycling was considered "Very Important" or "Important" for more than $98 \%$ of the students (table 2 ), while $58 \%$ thought that was simply "Easy" or "Very Easy" to practice it in their daily lives (table 3) and almost 90\% had already recycled something “Always (Yes)" or "Sometimes” (table 4).

Table 2. Attitude results $\left(n=113 ; X^{2}=7.89, p=0.79\right)$ for "Always wash and separate packages for recycling"

\begin{tabular}{|c|c|c|c|c|}
\hline Alternatives & $\mathbf{6}^{\text {th }}$ & $\mathbf{7}^{\text {th }}$ & $\mathbf{8}^{\text {th }}$ & $\mathbf{9}^{\text {th }}$ \\
\hline Not important & $\mathbf{0 \%}$ & $\mathbf{0 \%}$ & $\mathbf{0 \%}$ & $0 \%$ \\
\hline Little important & $0 \%$ & $3 \%$ & $0 \%$ & $0 \%$ \\
\hline Indifferent & $0 \%$ & $0 \%$ & $0 \%$ & $0 \%$ \\
\hline Important & $34 \%$ & $34 \%$ & $61 \%$ & $34 \%$ \\
\hline Very important & $\mathbf{6 6 \%}$ & $\mathbf{6 3 \%}$ & $39 \%$ & $\mathbf{6 6 \%}$ \\
\hline
\end{tabular}

Table 3. Behaviour constraint results $(n=113$; $X^{2}=11.61, p=0.48$ ) for "Always wash and separate packages for recycling"

\begin{tabular}{|c|c|c|c|c|}
\hline Alternatives & $6^{\text {th }}$ & $7^{\text {th }}$ & $8^{\text {th }}$ & $9^{\text {th }}$ \\
\hline Very easy & $38 \%$ & $17 \%$ & $14 \%$ & $19 \%$ \\
\hline Easy & $28 \%$ & $41 \%$ & $36 \%$ & $37 \%$ \\
\hline $\begin{array}{c}\text { Neither easy nor } \\
\text { difficult }\end{array}$ & $28 \%$ & $24 \%$ & $32 \%$ & $30 \%$ \\
\hline Difficult & $7 \%$ & $14 \%$ & $18 \%$ & $7 \%$ \\
\hline Very difficult & $0 \%$ & $3 \%$ & $0 \%$ & $7 \%$ \\
\hline
\end{tabular}

Table 4. Real behaviour performance results $(n=103$; $X^{2}=3.32, p=0.77$ ) for "Always wash and separate packages for recycling"

\begin{tabular}{|c|c|c|c|c|}
\hline Alternatives & $6^{\text {th }}$ & $7^{\text {th }}$ & $\mathbf{8}^{\text {th }}$ & $\mathbf{9}^{\text {th }}$ \\
\hline Yes & $43 \%$ & $41 \%$ & $39 \%$ & $59 \%$ \\
\hline No & $14 \%$ & $11 \%$ & $11 \%$ & $11 \%$ \\
\hline Sometimes & $43 \%$ & $48 \%$ & $50 \%$ & $30 \%$ \\
\hline
\end{tabular}

Tables 5, 6 and 7 show the answers related to the statement "I have always encouraged other people to act more sustainably". While almost all students (98\%) considered this action "Important" or "Very Important", they do not consider it a "Very Easy" or "Easy" task in their daily lives (45\%). Despite that, most of the students (80\%) attest that "Always (Yes)" or "Sometimes" they have tried to stimulate other people to act more sustainably.

Table 5. Attitude results $\left(n=113 ; X^{2}=6.94, p=0.86\right)$ for "I have always encouraged other people to act more sustainably"

\begin{tabular}{|c|c|c|c|c|}
\hline Alternatives & $\mathbf{6}^{\text {th }}$ & $\mathbf{7}^{\text {th }}$ & $\mathbf{8}^{\text {th }}$ & $\mathbf{9}^{\text {th }}$ \\
\hline Not important & $\mathbf{0 \%}$ & $\mathbf{0 \%}$ & $\mathbf{0 \%}$ & $\mathbf{0 \%}$ \\
\hline Little important & $\mathbf{0 \%}$ & $\mathbf{0 \%}$ & $\mathbf{0 \%}$ & $\mathbf{0 \%}$ \\
\hline Indifferent & $\mathbf{0 \%}$ & $\mathbf{3 \%}$ & $\mathbf{0 \%}$ & $\mathbf{4} \%$ \\
\hline Important & $\mathbf{1 4 \%}$ & $\mathbf{2 1 \%}$ & $\mathbf{2 1 \%}$ & $\mathbf{3 7 \%}$ \\
\hline Very important & $\mathbf{8 6 \%}$ & $\mathbf{7 6 \%}$ & $\mathbf{7 9 \%}$ & $\mathbf{5 9 \%}$ \\
\hline
\end{tabular}

Table 6. Behaviour constraint results $(n=106$; $X^{2}=12.55, p=0.40$ ) for "I have always encouraged other people to act more sustainably"

\begin{tabular}{|c|c|c|c|c|}
\hline Alternatives & $6^{\text {th }}$ & $7^{\text {th }}$ & $\mathbf{8}^{\text {th }}$ & $\mathbf{9}^{\text {th }}$ \\
\hline Very easy & $\mathbf{2 7 \%}$ & $\mathbf{2 1 \%}$ & $\mathbf{1 4 \%}$ & $19 \%$ \\
\hline Easy & $36 \%$ & $21 \%$ & $21 \%$ & $26 \%$ \\
\hline $\begin{array}{c}\text { Neither easy nor } \\
\text { difficult }\end{array}$ & $27 \%$ & $24 \%$ & $36 \%$ & $30 \%$ \\
\hline Difficult & $\mathbf{5 \%}$ & $31 \%$ & $\mathbf{2 9} \%$ & $15 \%$ \\
\hline Very difficult & $\mathbf{5 \%}$ & $3 \%$ & $0 \%$ & $11 \%$ \\
\hline
\end{tabular}

Table 7. Real behaviour performance results $(n=106$; $X^{2}=7.34, p=0.29$ ) for "I have always encouraged other people to act more sustainably"

\begin{tabular}{|c|c|c|c|c|}
\hline Alternatives & $6^{\text {th }}$ & $7^{\text {th }}$ & $8^{\text {th }}$ & $9^{\text {th }}$ \\
\hline Yes & $32 \%$ & $34 \%$ & $36 \%$ & $48 \%$ \\
\hline No & $14 \%$ & $14 \%$ & $21 \%$ & $30 \%$ \\
\hline Sometimes & $55 \%$ & $52 \%$ & $43 \%$ & $22 \%$ \\
\hline
\end{tabular}

Tables 8, 9 and 10 show the answers related to the statement "I have always turned off the lights after leaving the room”.

In that case, most of the students (77\%) considered "Very Important” (77\%) and a "Very Easy" (70\%) task turning off the lights after leaving the room. Consistently, more than $83 \%$ of the students "Always (Yes)" perform that action. 
Table 8. Attitude results $\left(n=113 ; X^{2}=7.04, p=0.85\right)$ for "I have always turned off the lights after leaving the room"

\begin{tabular}{|c|c|c|c|c|}
\hline Alternatives & $6^{\text {th }}$ & $7^{\text {th }}$ & $\mathbf{8}^{\text {th }}$ & $9^{\text {th }}$ \\
\hline Not important & $0 \%$ & $0 \%$ & $0 \%$ & $0 \%$ \\
\hline Little important & $0 \%$ & $0 \%$ & $0 \%$ & $0 \%$ \\
\hline Indifferent & $4 \%$ & $0 \%$ & $0 \%$ & $4 \%$ \\
\hline Important & $6 \%$ & $24 \%$ & $25 \%$ & $30 \%$ \\
\hline Very important & $90 \%$ & $76 \%$ & $75 \%$ & $66 \%$ \\
\hline
\end{tabular}

Table 9. Behaviour constraint results $(n=105$; $X^{2}=10.98, p=0.53$ ) for "I have always turned off the lights after leaving the room"

\begin{tabular}{|c|c|c|c|c|}
\hline Alternatives & $6^{\text {th }}$ & $7^{\text {th }}$ & $\mathbf{8}^{\text {th }}$ & $\mathbf{9}^{\text {th }}$ \\
\hline Very easy & $71 \%$ & $69 \%$ & $68 \%$ & $70 \%$ \\
\hline Easy & $29 \%$ & $27 \%$ & $28 \%$ & $18 \%$ \\
\hline $\begin{array}{c}\text { Neither easy nor } \\
\text { difficult }\end{array}$ & $0 \%$ & $0 \%$ & $4 \%$ & $4 \%$ \\
\hline Difficult & $0 \%$ & $0 \%$ & $0 \%$ & $8 \%$ \\
\hline Very difficult & $0 \%$ & $4 \%$ & $0 \%$ & $0 \%$ \\
\hline
\end{tabular}

Table 10. Real behaviour performance results $(n=105$, $X^{2}=7.41, p=0.28$ ) for "I have always turned off the lights after leaving the room"

\begin{tabular}{|c|c|c|c|c|}
\hline Alternatives & $6^{\text {th }}$ & $7^{\text {th }}$ & $8^{\text {th }}$ & $9^{\text {th }}$ \\
\hline Yes & $90 \%$ & $76 \%$ & $86 \%$ & $85 \%$ \\
\hline No & $0 \%$ & $0 \%$ & $4 \%$ & $7 \%$ \\
\hline Sometimes & $10 \%$ & $24 \%$ & $11 \%$ & $7 \%$ \\
\hline
\end{tabular}

Tables 11, 12 and 13 present the answers to the statement "Always encourage others to have a more sustainable behaviour".

Almost all of the students surveyed presented a very positive attitude about encouraging others to act more sustainably.

At the same time, $26 \%$ of the students considered "Difficult" or "Very Difficult" to perform that task. Following this pattern, almost $20 \%$ of the students never (no) stimulate others to develop more sustainable way of acting.

Table 11. Attitude results $\left(n=113 ; X^{2}=6.94 ; p=0.86\right)$ for "Always encourage others to have a more sustainable behaviour"

\begin{tabular}{|c|c|c|c|c|}
\hline Alternatives & $6^{\text {th }}$ & $7^{\text {th }}$ & $\mathbf{8}^{\text {th }}$ & $\mathbf{9}^{\text {th }}$ \\
\hline Not important & $0 \%$ & $0 \%$ & $0 \%$ & $0 \%$ \\
\hline Little important & $0 \%$ & $0 \%$ & $0 \%$ & $0 \%$ \\
\hline Indifferent & $0 \%$ & $3 \%$ & $0 \%$ & $4 \%$ \\
\hline Important & $14 \%$ & $21 \%$ & $21 \%$ & $37 \%$ \\
\hline Very important & $\mathbf{8 6 \%}$ & $\mathbf{7 6} \%$ & $\mathbf{7 9} \%$ & $59 \%$ \\
\hline
\end{tabular}

Table 12. Behaviour constraint results $(n=106$; $X^{2}=12.55, p=0.40$ ) for "Always encourage others to have a more sustainable behaviour"

\begin{tabular}{|c|c|c|c|c|}
\hline Alternatives & $6^{\text {th }}$ & $7^{\text {th }}$ & $8^{\text {th }}$ & $9^{\text {th }}$ \\
\hline Very easy & $27 \%$ & $20 \%$ & $14 \%$ & $18 \%$ \\
\hline Easy & $36 \%$ & $20 \%$ & $22 \%$ & $26 \%$ \\
\hline $\begin{array}{c}\text { Neither easy nor } \\
\text { difficult }\end{array}$ & $27 \%$ & $24 \%$ & $36 \%$ & $30 \%$ \\
\hline Difficult & $5 \%$ & $31 \%$ & $28 \%$ & $15 \%$ \\
\hline Very difficult & $5 \%$ & $5 \%$ & $0 \%$ & $11 \%$ \\
\hline
\end{tabular}

Table 13. Real behaviour performance results $(n=106$, $X^{2}=7.34, p=0.29$ ) for "Always encourage others to have a more sustainable behaviour"

\begin{tabular}{|c|c|c|c|c|}
\hline Alternatives & $6^{\text {th }}$ & $7^{\text {th }}$ & $8^{\text {th }}$ & $9^{\text {th }}$ \\
\hline Yes & 32 & 35 & 36 & 48 \\
\hline No & 14 & 14 & 21 & 27 \\
\hline Sometimes & 54 & 51 & 43 & 25 \\
\hline
\end{tabular}

It is interesting to notice the answers related to consumerism: "I have always consume/bought only the essential”. Through the analyses of the tables 14 to 18 , it is possible to note that the $9^{\text {th }}$ grade showed some difference related to the other grades students, considering that action less important than $6^{\text {th }}$ graders. At the same time they showed more difficulty involving that practice than all other students surveyed (table 16). But more than $86 \%$ of the students answered that they have "Always (Yes)" or "Sometimes" have consumed only the essential.

Table 14. Attitude results $\left(n=113 ; X^{2}=23.71, p=0.02\right)$ for "I have always consumed/bought only the essential"

\begin{tabular}{|c|c|c|c|c|}
\hline Alternatives & $\mathbf{6}^{\text {th }}$ & $\mathbf{7}^{\text {th }}$ & $\mathbf{8}^{\text {th }}$ & $\mathbf{9}^{\text {th }}$ \\
\hline Not important & $\mathbf{0 \%}$ & $\mathbf{3} \%$ & $\mathbf{0 \%}$ & $\mathbf{7 \%}$ \\
\hline Little important & $\mathbf{0 \%}$ & $\mathbf{0 \%}$ & $\mathbf{4 \%}$ & $\mathbf{0 \%}$ \\
\hline Indifferent & $\mathbf{0 \%}$ & $\mathbf{2 1 \%}$ & $\mathbf{0 \%}$ & $\mathbf{7 \%}$ \\
\hline Important & $\mathbf{3 5 \%}$ & $\mathbf{1 7 \%}$ & $\mathbf{3 9 \%}$ & $\mathbf{4 4 \%}$ \\
\hline Very important & $\mathbf{6 5 \%}$ & $\mathbf{5 9 \%}$ & $\mathbf{5 7 \%}$ & $\mathbf{4 2 \%}$ \\
\hline
\end{tabular}

Table 15. Wilcoxon test analyzes of attitudes ( $\alpha=5 \%)$ among grades for "I have always consumed/bought only the essential"

\begin{tabular}{|c|c|c|}
\hline Pairwise & $\mathbf{Z}$ & $\mathbf{p}>\mathbf{Z}$ \\
\hline $\mathbf{6}^{\mathbf{0}} \times \mathbf{7}^{\mathbf{0}}$ & $\mathbf{1 , 1 5}$ & $\mathbf{0 , 1 2}$ \\
\hline $\mathbf{6}^{\mathbf{0}} \times \mathbf{8}^{\mathbf{o}}$ & $\mathbf{0 , 7 3}$ & $\mathbf{0 , 2 3}$ \\
\hline $\mathbf{6}^{\mathbf{0}} \times \mathbf{9}^{\mathbf{o}}$ & $\mathbf{2 , 1 6}$ & $\mathbf{0 , 0 2}$ \\
\hline $\mathbf{7}^{\mathbf{0}} \times \mathbf{8}^{\mathbf{0}}$ & $-0,50$ & 0,69 \\
\hline $\mathbf{7}^{\mathbf{0}} \times \mathbf{9}^{\mathbf{0}}$ & $\mathbf{0 , 7 7}$ & $\mathbf{0 , 2 2}$ \\
\hline $\mathbf{8}^{\mathbf{0}} \times \mathbf{9}^{\mathbf{0}}$ & $\mathbf{1 , 4 6}$ & $\mathbf{0 , 0 7}$ \\
\hline
\end{tabular}


Table 16. Behaviour constraint results $(n=106$; $X^{2}=26.52, p=0.01$ ) for "I have always consumed/bought only the essential”

\begin{tabular}{|c|c|c|c|c|}
\hline Alternatives & $6^{\text {th }}$ & $7^{\text {th }}$ & $\mathbf{8}^{\text {th }}$ & $\mathbf{9}^{\text {th }}$ \\
\hline Very easy & $14 \%$ & $10 \%$ & $21 \%$ & $11 \%$ \\
\hline Easy & $45 \%$ & $41 \%$ & $14 \%$ & $4 \%$ \\
\hline $\begin{array}{c}\text { Neither easy nor } \\
\text { difficult }\end{array}$ & $23 \%$ & $21 \%$ & $25 \%$ & $33 \%$ \\
\hline Difficult & $14 \%$ & $21 \%$ & $36 \%$ & $26 \%$ \\
\hline Very difficult & $4 \%$ & $7 \%$ & $4 \%$ & $26 \%$ \\
\hline
\end{tabular}

Table 17. Wilcoxon test analyzes of behaviour constraints ( $\alpha=5 \%)$ among grades for "I have always consumed/bought only the essential”

\begin{tabular}{|c|c|c|}
\hline Pairwise & $z$ & $p>Z$ \\
\hline $6^{\circ} \times 7^{0}$ & $-0,69$ & 0,24 \\
\hline $6^{\circ} \times 8^{\circ}$ & $-1,17$ & 0,12 \\
\hline $6^{\circ} \times 9^{\circ}$ & $-2,93$ & 0,00 \\
\hline $7^{0} \times 8^{\circ}$ & $-0,54$ & 0,71 \\
\hline $7^{\circ} \times 9^{\circ}$ & $-2,49$ & 0,01 \\
\hline $8^{\circ} \times 9^{\circ}$ & $-1,86$ & 0,03 \\
\hline
\end{tabular}

Table 18. Real behaviour performance results $(n=91$, $X^{2}=9.41, p=0.15$ for "I have always consumed/bought only the essential"

\begin{tabular}{|c|c|c|c|c|}
\hline Alternatives & $6^{\text {th }}$ & $7^{\text {th }}$ & $8^{\text {th }}$ & $\mathbf{9}^{\text {th }}$ \\
\hline Yes & $54 \%$ & $29 \%$ & $32 \%$ & $22 \%$ \\
\hline No & $14 \%$ & $0 \%$ & $14 \%$ & $18 \%$ \\
\hline Sometimes & $32 \%$ & $71 \%$ & $54 \%$ & $60 \%$ \\
\hline
\end{tabular}

Another question that is important point out is related to bathing: "Do you take a 5-minute shower every day?”

As shown in tables 19, 20 and 21, all students considered this act "Important" or "Very Important" for sustainability, but when it came to practice the answers where divided. Only 44\% considered "Very Easy" or "Easy" to perform it every day, while $37 \%$ considered that "Very Difficult" or "Difficult", but only $28 \%$ are really not able to perform it in their daily lives.

Table 19. Attitude results $\left(n=113, X^{2}=14.31, p=0.28\right)$ for "Do you take a 5 -minute shower every day?"

\begin{tabular}{|c|c|c|c|c|}
\hline Alternatives & $\mathbf{6}^{\text {th }}$ & $\mathbf{7}^{\text {th }}$ & $\mathbf{8}^{\text {th }}$ & $\mathbf{9}^{\text {th }}$ \\
\hline Not important & $\mathbf{3 \%}$ & $\mathbf{7 \%}$ & $\mathbf{0 \%}$ & $\mathbf{0 \%}$ \\
\hline Little important & $\mathbf{0 \%}$ & $\mathbf{0 \%}$ & $\mathbf{7 \%}$ & $\mathbf{7 \%}$ \\
\hline Indifferent & $\mathbf{7 \%}$ & $\mathbf{0 \%}$ & $\mathbf{1 1 \%}$ & $\mathbf{1 1} \%$ \\
\hline Important & $\mathbf{4 1} \%$ & $\mathbf{3 4 \%}$ & $\mathbf{4 6 \%}$ & $\mathbf{4 8 \%}$ \\
\hline Very important & $\mathbf{4 8} \%$ & $\mathbf{5 9 \%}$ & $\mathbf{3 6} \%$ & $\mathbf{3 3} \%$ \\
\hline
\end{tabular}

Table 20. Behaviour constraint results ( $n=106$, $X^{2}=11.90, p=0.45$ ) for "Do you take a 5-minute shower every day?"

\begin{tabular}{|c|c|c|c|c|}
\hline Alternatives & $6^{\text {th }}$ & $7^{\text {th }}$ & $8^{\text {th }}$ & $9^{\text {th }}$ \\
\hline Very easy & $23 \%$ & $28 \%$ & $11 \%$ & $11 \%$ \\
\hline Easy & $32 \%$ & $24 \%$ & $32 \%$ & $19 \%$ \\
\hline $\begin{array}{c}\text { Neither easy nor } \\
\text { difficult }\end{array}$ & $14 \%$ & $14 \%$ & $18 \%$ & $30 \%$ \\
\hline Difficult & $18 \%$ & $17 \%$ & $36 \%$ & $26 \%$ \\
\hline Very difficult & $14 \%$ & $17 \%$ & $4 \%$ & $15 \%$ \\
\hline
\end{tabular}

Table 21. Real behaviour performance results and $X^{2}$ analyzes $\left(n=106, X^{2}=8.12, p=0.23\right)$ for "Do you take a 5-minute shower every day?”

\begin{tabular}{|c|c|c|c|c|}
\hline Alternatives & $6^{\text {th }}$ & $7^{\text {th }}$ & $\mathbf{8}^{\text {th }}$ & $\mathbf{9}^{\text {th }}$ \\
\hline Yes & $32 \%$ & $38 \%$ & $32 \%$ & $33 \%$ \\
\hline No & $9 \%$ & $34 \%$ & $29 \%$ & $37 \%$ \\
\hline Sometimes & $59 \%$ & $28 \%$ & $39 \%$ & $30 \%$ \\
\hline
\end{tabular}

\subsection{Session 5}

At last, in session 5 we investigated how students were used to seeing their school regarding the concept of sustainability. Energy (25\%), paper (29\%) and water (15\%) were considered the top three resources more wasted in the school, from to the students' point of view.

Despite the clear concern about wasting and the school environment, only around $34 \%$ of the students affirmed that they would "certainly participate" in activities aiming the improvement of the school's environment and sustainability.

\section{Discussion and Conclusions}

The questionnaire was really effective in showing us the baseline of current knowledge, attitudes and behaviour towards sustainability among elementary students, and clearly indicated some possible directions to create different interventions inside the school (nonformal programme) and how to reorient the school curriculum (formal education).

Just a few topics covered by the survey showed significant differences between the grades which allow us to infer that their knowledge, attitudes and behaviours at that age (from 14 to 16 years old) are very similar. Besides, attitudes were a much better predictor of behaviour than knowledge.

Michalos et al. [12] research also found that attitudes are more influential that age, levels of education and knowledge for favourable behaviours regarding sustainability, reinforcing the importance of investigating attitudes instead of simply assessing knowledge.

It also became clear that Educational Institutions play a very important role on building a more sustainable world. 
The positive attitude regarding education and educational institutions was also found by Michalos et al. [13].

Michalos research work [12, 13] assessed knowledge, attitudes and behaviours of $10^{\text {th }}$ grade students (15 year olds). Considering a Likert-type scale running from "strongly agree" to "strongly disagree", the statement "Every person should receive education that teaches the knowledge, values and skills necessary for sustainable living in a community" was "strongly agree” for almost $40 \%$ of the students surveyed.

Regarding strictly to the concept of sustainability, it is possible to affirm that developing activities aiming to clarify all the complexity that lies behind the idea of sustainability could be the very first step to stimulate even more positive attitudes towards a more sustainable school and society among the students, and most importantly, ensure that they realize that the responsibility for that it is in the hands of everyone including themselves..

It was not a surprise to see that the students make a strong correlation between environmental and natural resources protection. Michalos et al. [13] also found that the top five ranked responses were on statements directly related to the environmental dimension, which agrees with our results.

According Ricketts [2] the modern concept of sustainability arose from a combination of the ideas and ideals from the environmentalism, social ecology and economics built and settled back in the 1960s and 1970s. So, it is predictable that the modern concept of sustainability is still strongly related in a broad sense to environmental preservation and conservation.

Through the analyses of the attitude-behaviour pairwise, it is really interesting to note that most of the students have really positive attitudes regarding all different situations and actions presented in sessions 3 and 4. It was encouraging to see that not only environmental protection related actions are important for the students, but also issues related to social and economic aspects of sustainability.

It was also encouraging to note that a significant group of young students are already concerned about other's behaviours, and that they are trying to disseminate good practices.

Despite their positive attitudes, some clear gaps between attitudes, behavioural constraints and daily actions (saving water and consumerism, for instance) were noticed. And yet it is important to point out that those are very sensitive issues in the lives not only of elementary students, but for most of the world's population.

Despite the small sample of students surveyed, it was possible for us to better understand how elementary students think and act, and the relationship they have established between their daily lives and the concept of sustainability.

Besides the work that should be done to increase the knowledge regarding sustainability, it is crucial to intervene in every identified gap between attitude and behaviour and afterwards analyze the results among the elementary students.
In 2011, we are already planning some intervention projects for the school taking into account some of the results from this questionnaire. Our primary goal is to create a communication campaign inside the school in order to raise awareness about recycling, since students strongly associate sustainability to recycling.

We believe this is just the very first step to better understand how, and mostly important when, to start working in a more systematized way about sustainability inside and outside the classroom.

\section{Acknowledgement}

We would like to thank the Colégio Bandeirantes for supporting this work. We would also like to thank all the students and teachers that helped us during the survey and special thanks/credits to the teachers and students of the "Projeto Educação para a Sustentabilidade" whose work and enthusiasm has been of great importance for the success of this project.

\section{References}

[1] Dixon, J.A and Fallon, L.A., "The Concept of Sustainability: Origins, Extensions, and Usefulness for Policy", in Society and Natural Resources Vol.2, 1989, pp.73-84.

[2] Ricketts, G. M., The roots of sustainability, Acad. Quest. 23, 2010, pp. 20-53.

[3] Timpson, W. M. et alli, 147 Tips for Teaching Sustainability, Atwood Publishing, Madison, WI, 2006.

[4] McKeown, R., Education for Sustainable Development Toolkit, UNESCO, version 2, 2002.

[5] U.S. Government Printing Office, Superintendent of Documents, Mail Stop: SSOP, Education for Sustainability: An Agenda for Action, Washington, DC., 1996.

[6] Eco-Schools International Programme, Echo-Schools Programme, Lisbon, Portugal, 2009.

[7] Jacobson, S. K. et alli, Conservation Education and Outreach Techniques, Oxford University Press, Oxford, 2006.

[8] Gil, A. C., Métodos e técnicas de pesquisa social, Editora Atlas, São Paulo, 2009.

[9] Likert, R., A Technique for the Measurement of Attitudes, Archives of Psychology 140, 1932, pp.1-55.

[10] Zar, J. H., Biostatistical analysis, $3^{\text {rd }}$ edition, New Jersey, Prentice-Hall International, 1996.

[11] Bussab W. O. and Morettin P. A., Estatística Básica, $5^{\text {th }}$ edition, São Paulo, Saraiva, 2006.

[12] Michalos, A. C. et alli, Knowledge, attitudes and Behaviours. Concerning education for Sustainable Development: Two exploratory studies. Social Indicators Research 100, 2011, pp. 391-413. 
Literacy Information and Computer Education Journal (LICEJ), Volume 2, Issue 1, March 2011

[13] Michalos, A. C. et alli, Measuring knowledge, attitudes and behaviours concerning sustainable development among tenth grade students in Manitoba, Social Indicators Research, 2011-02-24, pp. 1-26. 